\title{
Cytomorphological Behaviour of Primary Trisomics in Pearl Millet (Pennisetum americanum (L.) Leeke)
}

\author{
R. Sai Kumar, U. P. Singh, R. B. Singh and R. M. Singh \\ Department of Genetics and Plant Breeding, Institute of Agriculture, \\ Banaras Hindu University VARANASI 221005 , India
}

Received July 29. 1980

The usefulness of trisomic series in cytogenetic and breeding researches of diploid species is well known and has been adequately discussed by Burnham (1965), Hermsen (1970) and Khush (1973). Since the initial discovery of trisomics in Datura (Blakeslee 1922), trisomic sets have been produced in several diploid species (for reference see Khush loc cit). Gill et al. (1970b) reported complete set of trisomics in pearl millet inbred Bil-4. Detailed study on cytogenetics of aneuploids and translocations in pearl millet is also being carried out by Singh and coworkers (Tyagi and Singh 1975, Tyagi 1976 and Nameeta 1973). The present study was undertaken with the objective of isolation, identification and characterization of cytomorphological behaviour of certain trisomics in pearl millet.

\section{Materials and methods}

Of the sixteen primary trisomics, six primary trisomic plants were isolated in the progeny of a single partial desynaptic line, nine in the progeny of crosses of triploid with standard normal and one in the progeny of interchange heterozygote. The important meiotic figures were photographed with the help of an Olympus camera with PM 6 attachment using $15 \times$ ocular and $100 \times$ oil immersion objective. Cinematographic 55 NP ORWO films were used for taking the photographs.

Pollen sterility was expressed as percentage of sterile pollen grains to the total pollen grains counted. On an average $400-500$ pollen grains per plant were counted. The morphological characters of each trisomic plant were noted. The trisomics were classified according to Gill et al. (1970b) and Nameeta (1973).

\section{Results}

\section{Morphological Behaviour of the Primary Simple Trisomics}

The primary simple trisomics were distinguishable from their diploid sibs by their poor seedling vigour, singnificantly shorter stature and narrower grassy leaf and stem. The data on certain morphological characters are presented in Table 1. On the basis of their morphology they were classified into following five types:

Bushy: It was characterised by its bushy habit, profuse tillering, narrow and somewhat linear leaves. There were six plants in this class.

Awned: Characterised by awned ears a single plant in this group was tallest among the trisomics and in other characteristics resembled normal. 
Slender: Three plants in this class showed singificantly reduced vigour and were extremely poor in tillering.

Dark Green: This group consisted of four plants which had dark green leaves and particulary the upper ones were very small and narrow. The plant height was only slightly reduced but with poor tillering.

Tiny: The plants (two in number) were extremely weak and dwarf among. the trisomics and possessed lowest number of leaves and tillers per plant.

Table 1. Morphological characteristics of the five trisomics as compared to the Normal diploid Pennisetum typhoides

\begin{tabular}{|c|c|c|c|c|c|c|}
\hline $\begin{array}{c}\text { Type of } \\
\text { trisomics }\end{array}$ & $\begin{array}{c}\text { Height } \\
(\mathrm{cm})\end{array}$ & $\begin{array}{l}\text { No. of } \\
\text { leaves }\end{array}$ & $\begin{array}{c}\text { Tiller } \\
\text { number }\end{array}$ & $\begin{array}{l}\text { Leaf length } \\
(\mathrm{cm})\end{array}$ & $\begin{array}{l}\text { Leaf width } \\
(\mathrm{cm})\end{array}$ & $\begin{array}{c}\text { Pollen } \\
\text { sterility }\end{array}$ \\
\hline Normal diploid & 112.5 & 37 & 7 & 39.6 & 2.2 & 16.0 \\
\hline Bushy & 45.6 & 18 & 3 & 24.4 & 1.4 & 50.5 \\
\hline Awned & 62.0 & 19 & 2 & 27.6 & 1.2 & 42.5 \\
\hline Slender & 28.7 & 9 & 2 & 20.3 & 1.5 & 62.0 \\
\hline Dark green & 36.5 & 11 & 3 & 15.0 & 0.9 & 65.5 \\
\hline \multirow[t]{4}{*}{ Tiny } & 27.5 & 8 & 3 & 17.7 & 1.0 & 70.0 \\
\hline & & & Ear length & Ear girth & Awns chara & \\
\hline & \multirow{2}{*}{\multicolumn{2}{|c|}{$\begin{array}{l}\text { Normal diploid } \\
\text { Awned }\end{array}$}} & 24.6 & 4.3 & \multirow{2}{*}{\multicolumn{2}{|c|}{$\begin{array}{l}\text { Awnless } \\
\text { Awns are present }\end{array}$}} \\
\hline & & & 18.7 & 3.6 & & \\
\hline
\end{tabular}

Table 2. Frequency of different chromosome associations at diakinesis and metaphase I in the five trisomics of Pennisetum typhoides.

\begin{tabular}{|c|c|c|c|c|c|c|c|c|}
\hline \multirow{3}{*}{$\begin{array}{l}\text { Type of } \\
\text { trisomics }\end{array}$} & \multirow{2}{*}{\multicolumn{2}{|c|}{$\begin{array}{l}\text { No. of cells } \\
\text { analysed }\end{array}$}} & \multicolumn{6}{|c|}{ Chromosome Associations } \\
\hline & & & \multicolumn{2}{|c|}{$6^{\mathrm{II}}+1^{\mathrm{III}}$} & \multicolumn{2}{|c|}{$7^{11}+1^{1}$} & \multicolumn{2}{|c|}{ Others } \\
\hline & Dia- & Meta-I & Dia- & Meta-I & Dia- & Meta-I & Dia- & Meta-I \\
\hline Bushy & 118 & 151 & 72 & 81 & 44 & 69 & 2 & 1 \\
\hline Awned & 128 & 91 & 78 & 54 & 50 & 35 & - & 2 \\
\hline Slender & 89 & 92 & 64 & 56 & 22 & 36 & 3 & - \\
\hline Dark green & 92 & 89 & 61 & 64 & 31 & 24 & - & 1 \\
\hline Tiny & 173 & 87 & 125 & 66 & 48 & 21 & - & - \\
\hline Total & 600 & 510 & 400 & 321 & 195 & 185 & 5 & 4 \\
\hline Mean per cent & & & 66.7 & 62.9 & 32.5 & 36.3 & 0.8 & 0.8 \\
\hline
\end{tabular}

Meiotic Behaviour of the Primary Trisomics

Meiotic chromosome associations and trivalent types at diakinesis and metaphase I and chromosome separation at anaphase I were studied in the five groups of primary trisomics (Figs. 1 to 23).

All the primary trisomics showed one trivalent and six bivalents or seven bivalents and one univalent at diakinesis and metaphase I. Tables 2 and 3 give the frequency of chromosome associations and types of trivalents at diakinesis and metaphase $I$. It may be noted that the frequency of cells showing $1^{\text {III }}+6^{\text {II }}$ at diakinesis (Figs. 2 to 9) was 66.7 per cent and at metaphase I (Figs. 11, 13, 14 and 16) it was 62.9 per cent. The frequency of cells exhibiting $7^{11}+1^{1}$ at diakinesis 
and metaphase I (Fig. 12) was 32.5 per cent and 36.3 per cent, respectively. Other types of chromosome associations at diakinesis such as $6^{\mathrm{II}}+3^{\mathrm{I}}$ and $5^{\mathrm{II}}+1^{\mathrm{III}}+2^{\mathrm{I}}$ were observed in 0.8 per cent of the cells.

The three homologous chromosomes of a trisomic showed V-, inverted S, L-, Y-, frying pan, S- and J-shape configurations. The chain of three (Fig. 14) was

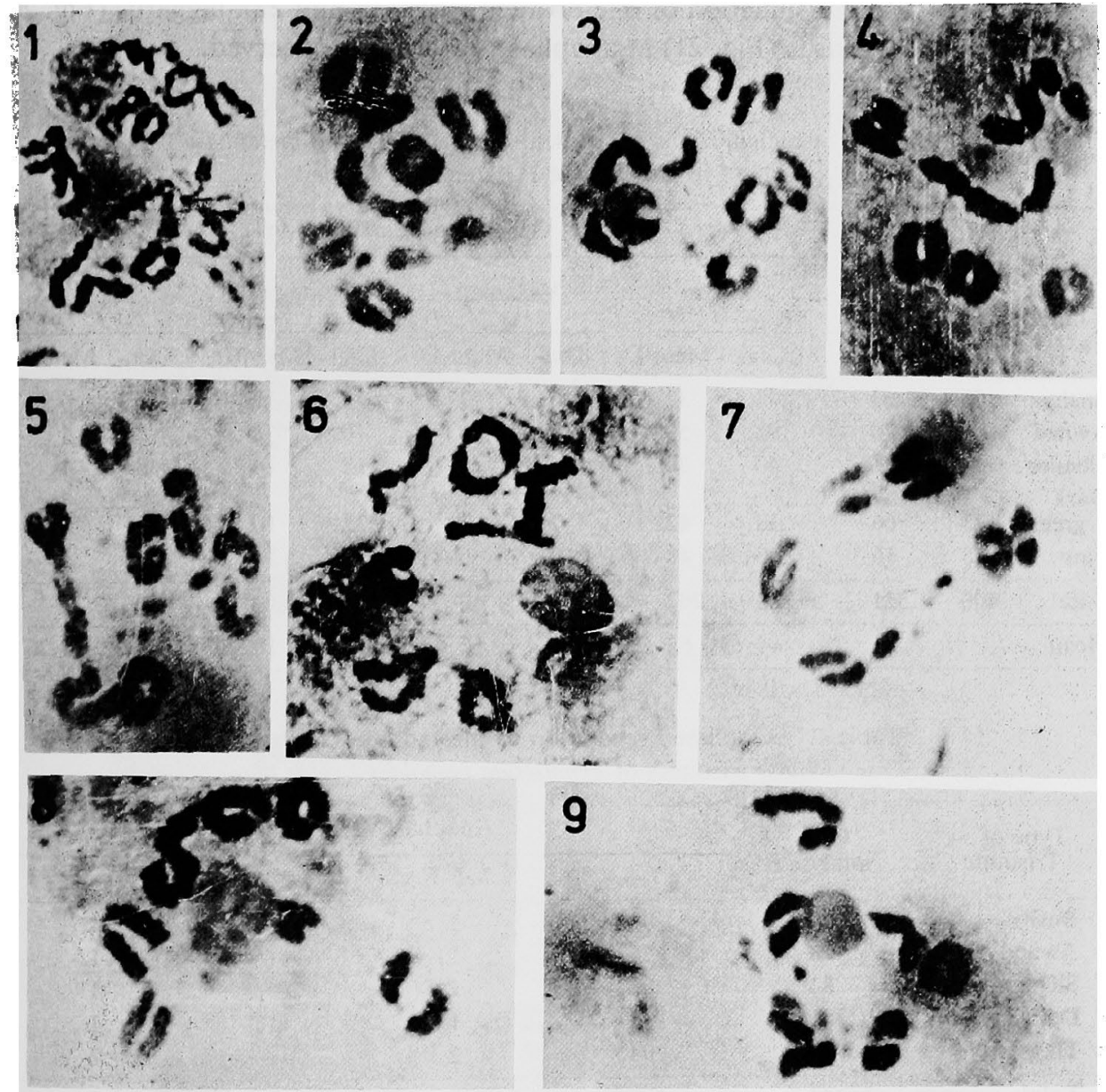

Figs. 1-9. Different trivalent types at diakinesis. Magnification. $\times 500$. 1 , diplotene, $5^{11}+1^{\mathrm{v}}$. 2, diakinesis, $6^{\mathrm{II}}+1^{\mathrm{III}}$, V-shaped. 3, diakinesis, $6^{\mathrm{II}}+1^{\mathrm{III}}$, inverted $\mathrm{S}$-shaped. 4, diakinesis, $6^{\mathrm{II}}+1^{\mathrm{III}}$, L-shaped. 5, diakinesis, $6^{\mathrm{II}}+1^{\mathrm{III}}$, Y-shaped. 6, diakinesis, $6^{1 \mathrm{I}}+1^{\mathrm{III}}$, 4-shaped. 7, diakinesis, $6^{\text {II }}+1^{111}$, Frying pan-shaped. 8, diakinesis, $6^{11}+1^{111}$, S-shaped. 9, diakinesis, $6^{\text {II }}+$ 1III, J-shaped.

the most frequent configuration, being 65 per cent at diakinesis and 63 per cent at metaphase I followed by frying pan (Fig. 7, approx. 19 per cent both at diakinesis and metaphase I). Other types of configurations (Figs. 2 to 9) at diakinesis were observed in about 8 per cent of the cells. At metaphase I frequency of V-shape (Fig. 16) trivalents increased (12 per cent), whereas, other types of configurations decreased ( 6 per cent). Chromosome length influenced the frequency of different 
configurations. Shorter chromosomes had the higher frequency of chain trivalents and lower frequency of $\mathrm{Y}$-shape and frying pan trivalents at diakinesis and metaphase I.

Separation of chromosomes at anaphase I is clearly seen in Figs. 17 to 23. In primary trisomics eight vs. seven chromosomes separation was most frequent (Fig. 17 and Table 4). Certain abnormalities such as 8-1-6 separation of chromosomes (Fig. 19), late disjunction of one bivalent (Figs. 18 and 22), laggards (Fig. 20) and splitting of laggards (Fig. 21) at anaphase I were also observed.

Table 3. Configurations of trivalents at diakinesis and metaphase I in the five trisomics of Pennisetum typhoides

\begin{tabular}{|c|c|c|c|c|c|c|c|c|c|c|}
\hline \multirow{3}{*}{$\begin{array}{c}\text { Type of } \\
\text { Triso- } \\
\text { mics }\end{array}$} & \multirow{2}{*}{\multicolumn{2}{|c|}{$\begin{array}{l}\text { Cells } \\
\text { analysed }\end{array}$}} & \multicolumn{8}{|c|}{ Chromosome associations } \\
\hline & & & \multicolumn{2}{|c|}{ Chain } & \multicolumn{2}{|c|}{ V-shaped } & \multicolumn{2}{|c|}{ Frying-pan } & \multicolumn{2}{|c|}{$\begin{array}{l}\text { Others } Y, J \\
\text { and S-shaped }\end{array}$} \\
\hline & Dia- & Meta-I & Dia- & Meta-I & Dia- & Meta-I & Dia- & Meta-I & Dia- & Meta-I \\
\hline Bushy & 76 & 63 & 48 & 32 & 6 & 9 & 16 & 16 & 6 & 6 \\
\hline Awned & 109 & 70 & 91 & 50 & 6 & 8 & 10 & 8 & 2 & 4 \\
\hline Slender & 64 & 56 & 40 & 30 & 4 & 8 & 12 & 14 & 8 & 4 \\
\hline $\begin{array}{l}\text { Dark } \\
\text { green }\end{array}$ & 73 & 66 & 38 & 42 & 7 & 9 & 22 & 10 & 6 & 5 \\
\hline Tiny & 78 & 66 & 46 & 48 & 10 & 6 & 14 & 11 & 8 & 1 \\
\hline Total & 400 & 321 & 263 & 202 & 33 & 40 & 74 & 59 & 30 & 20 \\
\hline Mean & & & 64.65 & 62.58 & 8.74 & 12.67 & 18.58 & 18.49 & 8.03 & 6.26 \\
\hline
\end{tabular}

Table 4. Anaphase I separation of chromosomes in the five trisomics of Pennisetum typhoides

\begin{tabular}{lccccc}
\hline \multirow{2}{*}{$\begin{array}{c}\text { Type of } \\
\text { Trisomic }\end{array}$} & $\begin{array}{c}\text { Cells } \\
\text { analysed }\end{array}$ & \multicolumn{4}{c}{ Anaphase separations } \\
\cline { 3 - 6 } & & $7-8$ & $7-1-7$ & $8-1-6$ & $9-6$ \\
\hline Bushy & 92 & 89 & 2 & - & 1 \\
Awned & 78 & 76 & 1 & 1 & 1 \\
Slender & 84 & 82 & 1 & - & 1 \\
Dark green & 88 & 85 & 1 & 1 & 1 \\
Tiny & 98 & 94 & 2 & - & 2 \\
\hline Total & 440 & 426 & 7 & 2 & 5 \\
\hline
\end{tabular}

Though the additional chromosome in the various trisomics was not identified karyotypically the relative frequencies of the bivalents + univalents and trivalents gave some indication regarding the size of the additional chromosome (Table 2). A comparison of morphological characters and pollen sterility of different primary trisomics indicated a relationship between the size of the additional chromosome and morphological characteristics of the trisomic. The larger chromosomes affected the morphology and pollen sterility drastically while the shorter chromosomes had minor effect. Probably tiny trisomic involved the largest chromosome which had negative effect on the different morphological traits (Table 1). 


\section{Discussion}

In the present investigation trisomics were produced from three different sources i.e., desynaptic plant, triploid and translocation heterozygote. The desynaptic plant showed univalents ranging from 0 to 13 at diakinesis and metaphase I. In triploid plant $36 \%$ of the cells showed eight chromosome separation to one pole at anaphase I. Of the three sources as reported in this case, trisomics were most

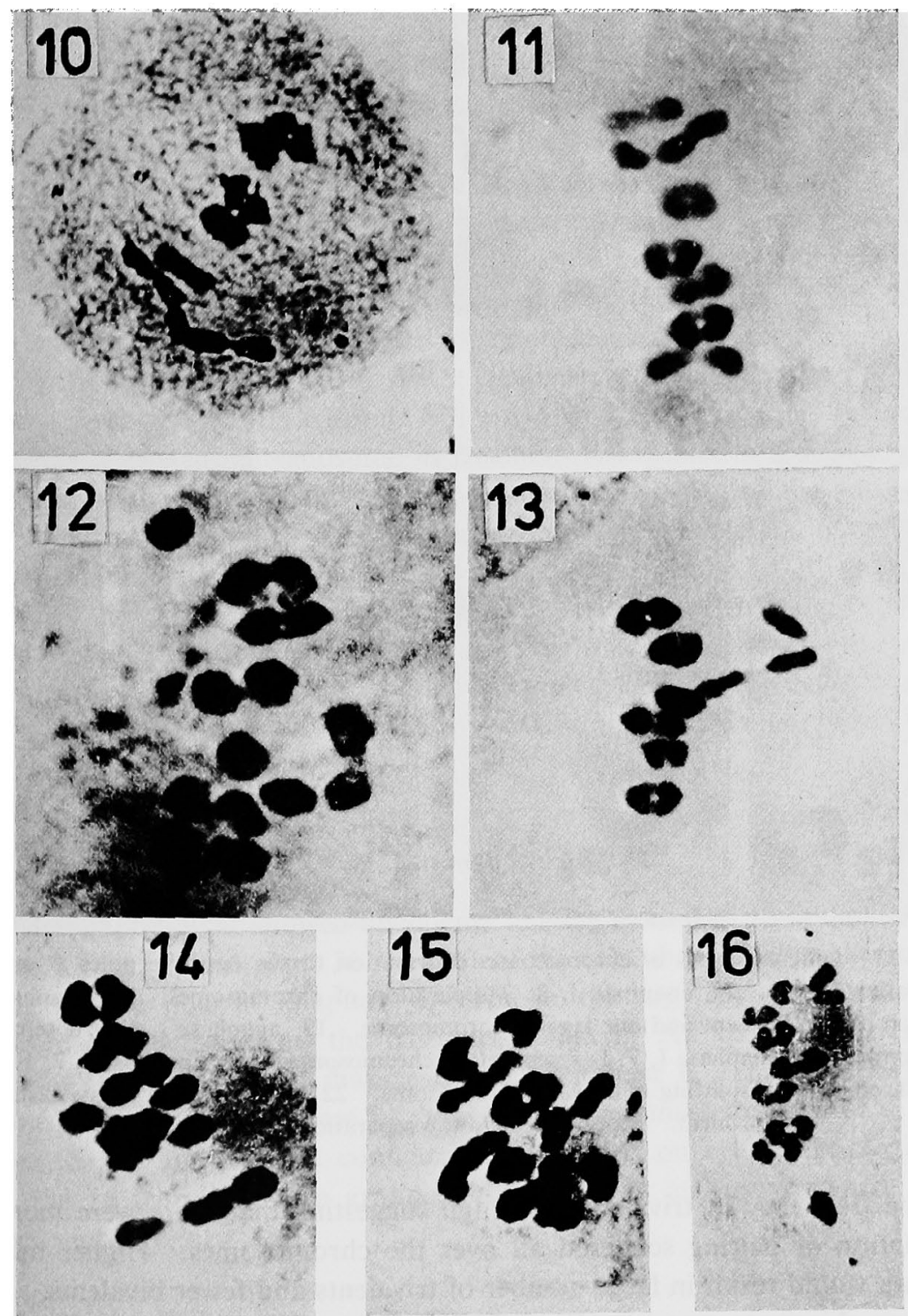

Figs. 10-16. Different chromosome associations and types of trivalents at metaphaes I. Magnification. $\times 500.10,5^{1 \mathrm{I}}+1^{\mathrm{v}}$, chain of five. $11,6^{\mathrm{II}}+1^{\mathrm{III}}$, chain type. $12,7^{\mathrm{II}}+1^{\mathrm{I}} .13,6^{\mathrm{II}}+$ $1^{\mathrm{III}}$, L-shaped. $14,6^{\mathrm{II}}+1^{\mathrm{III}}$, rod shaped, early disjunction of one bivalent. $15,6^{\mathrm{II}}+1^{\mathrm{III}}$, early disjunction of trivalent. $16,6^{11}+1^{111}, \mathrm{~V}$-shaped. 
frequent in the progeny of triploids.

The chromosome associations at diakinesis and metaphase I were usually $6^{\text {II }}+1^{\text {III }}$ or $7^{\text {II }}+1^{\mathrm{I}}$, whereas $6^{\text {II }}+3^{\mathrm{I}}$ were low in frequency. The trivalents exhibited different configurations, viz., chain, frying pan, Y-, J-, S- and 4-shaped. There was no characteristic meiotic configuration of the specific trisomics. In trisomics three homologues of one chromosome are available for paring. If pairing initiates at a single point only a bivalent and a univalent will be formed. In the present

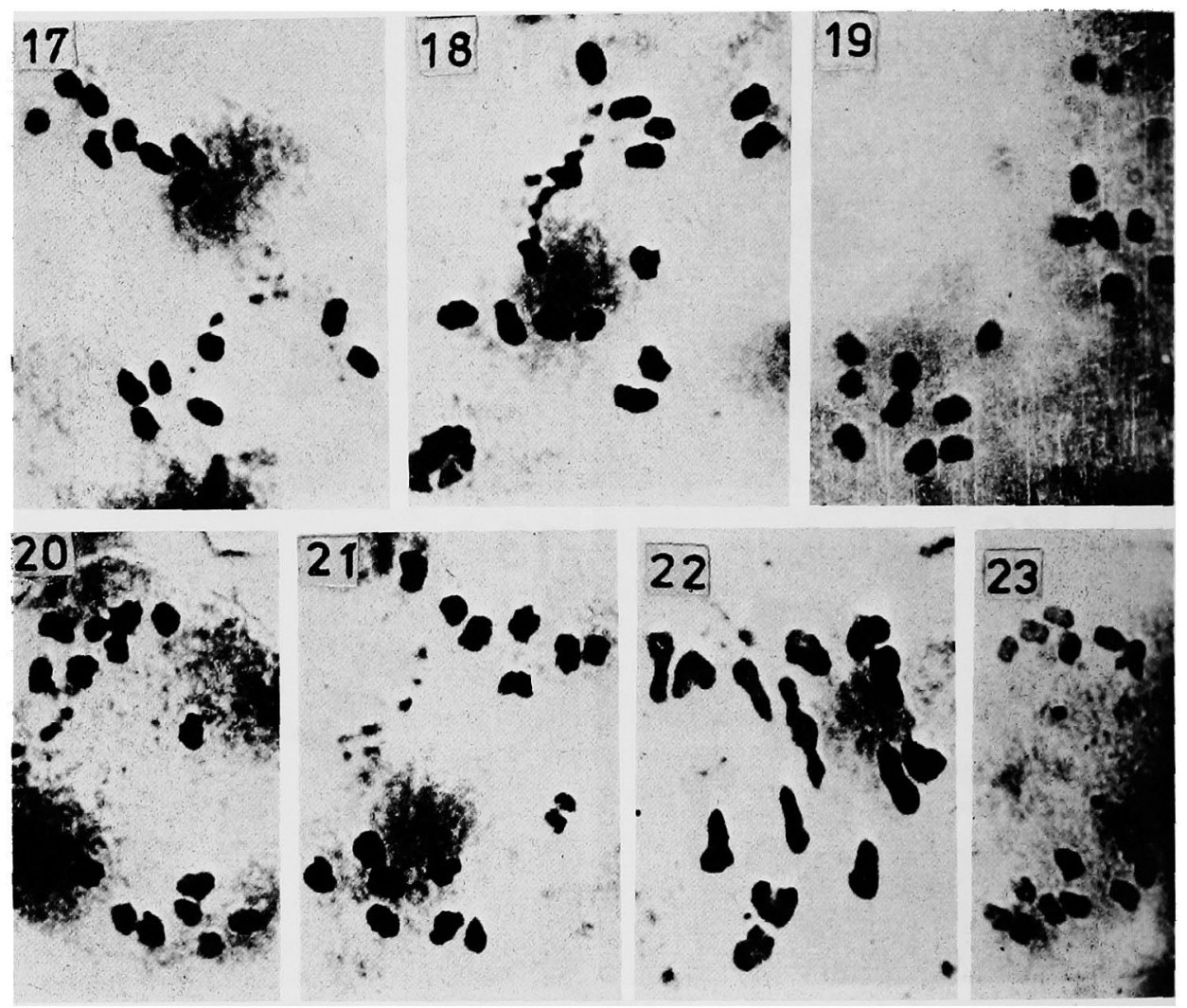

Figs. 17-23. Different types of chromosomes distribution to the opposite poles at anaphase $\mathbf{I}$. Magnification, $\times 500.17$, anaphase I, 8: 7 separation of chromosomes. 18, anaphase I, late disjunction of one bivalent and one lagging chromosome. 19, anaphase I, 8:1:6 separation of chromosomes. 20, anaphase I, 7:1:7 separation chromosomes. 21, anaphase I, 7:1:7 separation of chromosomes, splitting of laggard chromosome. 22, mid anaphase I, late disjunction of one bivalent. 23, anaphase I, 9: 6 separation of chromosomes.

study the frequency of trivalents was high suggesting that there were more points for initiation of pairing scattered all over the chromosomes. Higher number of chiasmata would result in large number of trivalents and fewer bivalents.

When chiasmata occur in all available segments the metaphase configuration reflects the pairing relations. The bivalent is usually a ring plus one univalent and the trivalent is a frying pan (Fig. 7). If interstitial chiasmata are few the trivalent will appear as chain (Fig. 14). but an occasional interstitial chiasma alongwith a distal 
chiasma in the same arm will result in a Y-shape configuration (Fig. 5) and in absence of chiasma the chromosomes will appear as three univalents. In the present investigation chain trivalent was observed in most of the cases, whereas $\mathrm{Y}$ and frying pan configurations were observed only in few cells suggesting that in pearl millet usually the chiasmata are terminally localized.

Anaphase chromosome separations were 7-8, 7-1-7 and 9-6 (Figs. 17, 20 and 23), the first category being most frequent (Table 4). It suggests that on selfing as well as on crossing with normal diploids the trisomics are likely to throw out good proportion of trisomics.

The five trisomics were distinguishable morphologically from diploids as well as from one another. The distinguishing features constituted general vigour, height, leaf width, stem thickness and panicle size. All trisomics had reduced vigour, shorter height, narrower leaves, thinner stem and smaller panicles.

Trisomics morphologically distinguishable from diploids have been reported in Datura (Blakeslee 1922), tomato (Rick and Barton 1954), barely (Tsuchiya 1967), sorghum (Schertz 1966), rice (Hu 1968), pearl millet (Gill et al. 1970b, Nameeta 1973). However, the trisomics were indistinguishable from the diploid sibs in Hyacinthus (Darlington et al. 1951), maize (Rhoades 1955). The phenotypic effect of the extra chromosome of a trisomic will obviously depend upon its gene content. The effect of additional chromosome in trisomics is expected to be in proportion to the length of the genome and the importance and vitality of the added genes. In general the trisomics showed reduction in important characters, the magnitude of which increased with increasing size of extra chromosome.

Each of the seven possible trisomics with specific diagnostic characteristics have been described by Gill et al. (1970b) and Nameeta (1973), which are consistent regardless of the varietal source. Though different genetic backgrounds may effect the expression of the extra chromosome to a certain extent, the main morphological traits remained similar.

\section{Summary}

The desynaptic plant showed univalents ranging from 0 to 13 at diakinesis and metaphase I. In triploid plant 36 per cent of the cells showed eight chromosomes separating to one pole at anaphase I. The morphology, cytology and sterility studies were conducted in all the trisomics isolated. All the primary trisomics showed $6^{\mathrm{II}}+1^{\mathrm{III}}$ or $7^{\mathrm{II}}+1^{\mathrm{I}}$ at diakinesis and metaphase $\mathrm{I}$. The frequency of trivalents was reduced at metaphase I. The trivalent resumed in chain of 3, V-, Y-, frying pan, S-, J- and 4-shape configurations. Based on cytomorphological distinction, the 16 trisomics were grouped in five classes as bushy, awned, slender, dark green and tiny.

\section{References}

Blakeslee, A. F. 1922. Variation in Datura due to changes in chromosome number. Amer. Nat. 56: $16-31$.

Burnham, C. R. 1962. Discussion in cytogenetics. Burgess Publ. Co. Minnesota. 
Darlington, C. D., Hair, J. B. and Hurcombe, R. 1951. The history of garden Hyacinthus. Heredity $5: 233-252$.

Gill, B. S., Virmani, S. S. and Minocha, J. L. 1970b. Primary simple trisomics in pearl millet. Can. J. Genet. Cytol. 12: 474-483.

Hermsen, J. G. Th, 1970. Basic information for the use of primary trisomics in genetic and breeding research. Euphytica 19: 125-140.

Hu, C. H. 1968. Establishment of a complete set of trisomics in rice. Proc. 12th Int. Cong. Genet. Tokyo. 1-177.

Khush, G. S. 1973. Cytogenetics of Aneuploids. Academic Press, New York and London.

Nameeta, N. 1973. Establishment of aneuploids and their use in pearl millet (Pennisetum typhoides (Burm) S. \& H.). Improvement. Ph. D. Thesis, Meerut University, Meerut, India.

Rhoades, M. M. 1955. The cytogenetics of maize and "In Corn and Corn Improvement." (G. F. Sprague, ed.) pp. 123-219. Academic Press, New York.

Rick, C. M, and Barton D. W. 1954. Cytological and genetical identification of the primary trisomics in tomato. Genetics 39:640-660.

Shertz, K. F. 1966. Morphological and cytological characteristics of five trisomics of Sorghum vulgare Pers. Crop Sci. 6: 519-523.

Tsuchiya, T. 1967. The establishment of trisomic series in a two rowed cultivated variety of barely. Can. J. Genet. Cytol. 9: 667-682.

Tyagi, B. R. and Singh, R. B. 1975 . Induced translocations in pearl millet. Nucleus 18 (i \& ii): 19-24.

- 1976. Extra chromosomes in primary simple trisomics of pearl millet in crosses with translocation testers. Nucleus 19 (ii): 112-114. 